\author{
Людмила Зарембо \\ Минск
}

\title{
Оним «Каялы» в Ипатьевской летописи
}

«Каяла» - поддержанная многими филологами исходная форма гидронима. Она реконструирована на основе трех известных сегодня древнерусских текстов, где представлены две ее падежные модификации «Каяль» и «Каялы»: в Ипатьевской летописи «Каялы», в «Слове о полку Игореве» «Каялы» и «Каяль», «Задонщине» по списку В. М. Ундольского «Каяль» 1 .

Своеобразным пиком в истории представления различных суждений по этому поводу на родине «Слова» стали середина и конец XX века, когда вышли в свет статья Л. А. Дмитриева «Глагол «каяти» и река Каяла в «Слове о полку Игореве»» $(1953)^{2}$, перевод на русский язык второго тома «Этимологического словаря русского языка» М. Фасмера $(1967)^{3}$ и затем обстоятельная статья А. Г. Боброва «Каяла (Каялы́)» в «Энциклопедии «Слова о полку Игореве»» $(1995)^{4}$. В упомянутом словаре читаем: «Каяла - река на юге Руси, СПИ («Слово о полку Игореве» - Л.З.). Из тюрк. Kajaly «скалистая»... Популярное сближение с ка́ятьься - по нар. этимологии. [Cp. первонач. Каяльl, Ипатьевск. летоп.]»5 . В этой же статье Фасмер приводит информа-

1 Словарь-справочник «Слова о полку Игореве», сост. В. Л. Виноградова, Ленинград 1967, вып. 2, с. 179.

2 Труды Отдела древнерусской литературы, Москва-Ленинград 1953, т. 9.

3 М. Фасмер, Этимологический словарь русского языка, Москва 1986, т. 1-4.

4 Энииклопедия «Слова о полку Игореве»: В 5 томах, СПб 1995, т. 3, с. 31-36.

5 М. Фасмер, Этимологический словарь..., т. 2, с. 216. 
цию о существовании «названия реки Каяльь в [бывш.] Оренбург. губ.» и несколько схожих по звучанию примеров ${ }^{6}$.

Разумеется, не отвергая напрочь гипотезу о восточных фонетико-лексических истоках слова «Каял[-а], [-ы], [-k]», как и перспективность поисков его этимонов в русской языковой среде (несклоняемая форма Каялы́; редкая форма местного падежа на «-ы» от основы склонения на «-а»; в летописи есть родительный падеж названия реки «Ка́яла»- место раскаяния, покаяния и т.п. от глагола «каяти»), полагаем, что не случайно, этот «русский» ряд вариантов продолжает и сейчас активно пополняться (см.: А. Г. Бобров, 19957; Л. В. Левшун, 2009 год: «Каяла... - аллегория реки братоубийства (производное от Каин), а не какая-то конкретная река», «Игорь... идет «на суд Божий» с братоубийственной Каялы через покаяние и раскаяние» 8 ; Л. Г. Мощенская, 2011 год: «каять(-ти)»-《кають» $\rightarrow$ краткое причастие действительного залога прошедшего времени именительного падежа единственного числа женского рода «каяла» (в текстах не обнаружено) $\rightarrow$ адъективированное прилагательное «каяла» $\rightarrow$ субстантивированное прилагательное «каяла» ${ }^{9}$ Л. И. Зарембо, 2012 год: «ККаяла» условная реконструированная исходная форма собственного имени существительного женского рода склонения на «-а» с неполной парадигмой в форме единственного числа родительного и местного падежей» ${ }^{10}$. Конечно же, гипотетические построения не претендуют на бесспорность и более того, весьма вероятно, что в исторической действительности ни один из предполагаемых путей «мутации» онима-лексемы не реализовался изолированно и самодостаточно. Для возможно более глубокого и совершенного прочтения текста со столь редким онимом, как представляется, исследовательскую цель надо ставить, хотя и близкую, но иную: конструировать не последовательность этимологической и грамматической цепи, а как восприни-

6 Там же.

7 Энциклопедия «Слова о полку Игореве»..., т. 3, с. 31-36.

8 Л. Левшун, О слове преображенном и слове преображающем: теоретико-аналитический очерк истории восточнославянского книжного слова XI-XVII веков, Минск 2009, с. 388, 408.

9 Л. Мощенская, Л. Зарембо, Новая конъектура темного места «Слова о полку Игореве» (река Каяла), [в:] Русский язык: система и функиионирование: Сб. материалов V Междунар. науч. конф. 11-12 окт. 2011 г., Минск, Минск 2011, c. $173-177$.

10 Л. Зарембо, О лексико-грамматическом значении онима «Каяла» в «Слове о полку Игореве», [в:] Карповские научные чтения: Сб. науч. ст., вып. 6, в 2-х ч., Минск 2012, ч. 2, с. 88-92. 
малось носителями русского языка «Каял(--), (-у)» в качестве продукта этого столь ярко вспыхнувшего и ограниченного во времени употребления, по возможности очертить узус слова. И сделать это непременно с учетом сверхзадач, которые реализуются в художественном гипертексте - Ипатьевская летопись, «Слово о полку Игореве» и «Задонщина». (Д. С. Лихачев назвал это явление «текстологическим треугольником» ${ }^{11}$.)

Упомянутые произведения, отстоящие друг от друга по времени и месту создания, объединяет прежде всего тема 1185 года. В их своеобразном художественном треугольнике креативная роль принадлежала, конечно же, более ранним - Ипатьевской летописи и «Слову о полку Игореве». При этом «Слово» выделяется особой интенсивностью в «закреплении» «Каял (-k), (-у)» за данным сюжетом. В нем название реки использовано шесть раз и при этом исключительно во фрагментах, связанных с событиями Игоревой рати, из них лишь однажды с указанием на аналогию: «Съ тоя же Каялы» $\left.{ }^{12}\right)$. Означенная актуализация номена становится особенно выразительной, если принять во внимание и некоторые статистические данные. Так, согласно подсчетам Б. А. Рыбакова, «описание «полка Игорева»... занимает со всеми художественными отступлениями лишь $1 / 5$ всего текста; 4/5 посвящено другим... важным темам»13. А это значит, что из 536 словоупотреблений каждое $89-\mathrm{e}-\ll$ Каял (-k), (-y)»14. И это в условиях высокоинтеллектуального текста, где из 976 слов 614, т. е. $63 \%$ словаря памятника, употреблено по одному разу ${ }^{15}$. Еще более впечатляют цифровые выкладки в этой области Д. С. Ворта. По его мнению, «Слово о полку Игореве» даже надлежит отторгнуть от комплекса европейского эпоса из-за ослабленной центральной повествовательной доминанты: «Лишь десятая часть стихов... посвящена описанию исторических событий (1185 года - Л.3.). Роль «композиционной сути произведения» выполняют «длительные и разнообразнейшие авторские «от-

11 См.: Д. Лихачев, «Текстологический треугольник»: «Слово о полку Игореве», рассказ Ипатьевской летописим о походе князя Игоря в 1185 2. и «Задонщина» (К текстологическим замечаниям проф. Дж. Феннелла), [в:] Д. Лихачев, «Слово о полку Игореве» и культура его времени, Ленинград 1978, с. 289, 299-301.

12 Энииклопедия «Слова о полку Игореве»..., т. 1, с. 10.

13 Б. Рыбаков, Петр Бориславич: Поиск автора «Слова о полку Игореве», Москва 1991, c. 23.

14 О суммарном количестве слов и словоупотреблений см.: Энциклопедия «Слова о полку Игореве»..., т. 3, с. 138.

15 Там же. 
ступления»». Они «составляют $90 \%$ всего «Слова»»16. В сопряжении с выделенной В. Л. Виноградовой общей суммой словоупотреблений (2680) это дает основания говорить о 44,7 частотности употребления «Каял (-t), (-у)» в сюжетной линии Игоря ${ }^{17}$. Сознавая некоторую степень приблизительности этих подсчетов, мы все же имеем право квалифицировать этот гидроним в качестве высокочастотного и потому ключевого слова поэмы о князе Игоре Святославиче. (По общепринятому мнению, высокая частотность считается важнейшим критерием для определения ключевых слов $\left.{ }^{18}\right)$. Особое внимание привлекает к себе и грамматическая плотность форм этой лексемы.

Как уже отмечалось, в «Слове о полку Игореве» зафиксированы лишь две модификации - формы родительного и местного падежей склонения существительных на (-а). Это «Каяль» (дважды «на рнц'

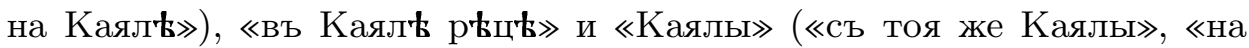
брезъ быстрой Каялы», «во дн' Каялы, рtккы половецкія»19. Что, по всей видимости, и позволило М. Фасмеру расценить «Каялы» в русской письменности как первоявленную: «Первонач. Каялы, Ипатьевск. лет.» ${ }^{20}$.

Исходя из приоритетности для нас тех признаков в семантическом поле «Каял (-k), (-у)», которые общи всем трем текстам, выделим на первое место чрезвычайно любопытный прием поэтической стилистики: всюду встречаем употребление «Каял (-k), (-у)» в устойчивой оппозиции «веселью» как ситуативному антониму. Сравним:

«Слово о полку Игореве»: «Ту ся брата разлучиста на брезњ быстрой Каялы; ...ту пир докончаша храбріи русичи... не веселая година въстала»; «Игорь погрузи жиръ во днњ Каялы... веселіе пониче»; «На рнцы на Каяль... А мы уже жадни веселия»; «Полечю,... омочю...

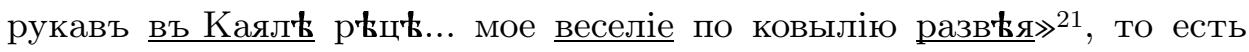
в четырех случаях из шести словоупотреблений - в $67 \%$.

Ипатьевская летопись: «Наведе на ня господь гнњвъ свои, в радости мkсто наведе на ны плачь и во веселье мtсто желю на ptцt Каялы»22.

16 Д. Ворт, Лирический элемент в «Слове о полку Игореве», [в:] «Слово о полку Игореве»: Комплекснье исследования, Москва 1988, с. 39-40.

17 Энииклопедия «Слова о полку Игореве»..., т. 3, с. 138.

18 См., напр.: Н. Николина, Филологический анализ текста, Москва 2003, с. 185.

19 Энииклопедия «Слова о полку Игореве»..., т. 1, с. 10, 11, 13.

20 М. Фасмер, Этимологический словарь..., т. 2, с. 216.

21 Энииклопедия «Слова о полку Игореве»..., т. 1, с. 11, 11-12, 13.

22 Цит. по: Словарь-справочник «ллова о полку Игореве»..., вып. 2, с. 179. 
Задонщина: «...поганые татаровя, бусормановя. Т $\mathbf{k}$ бо на рек Каяль одолеша родъ Афетовъ. И оттоля Руская земля сњдить невеселар ${ }^{23}$ (подчеркнуто - Л.3.).

Обращает на себя внимание, что в непосредственном продолжении текста «Задонщины» на хронологический фрагмент от битвы на реке Калке до Мамаева побоища автор не распространяет состояние «невеселия», тем самым как бы замыкая его корреспонденцию исключительно с «Каялой». Здесь употреблены его синонимы «туга» и «печаль», а также иные многословные коннотации-описания: «...а от Калатьския рати до Мамаева побоища тугою и печалию покрышася, плачющися, чады своя поминаючи - князи и бояря и удалые люди, иже оставиша вся домы своя и богатство, жены и дыти и скот, честь и славу мира сего получивши, главы своя положивша за землю за Рускую и за в $\mathbf{k p y ~}$ християнскую» ${ }^{24}$.

Далее отметим еще один важный, на наш взгляд, показатель: в семантическом поле «Каял (-t), (-y)» воплощен импульс некоей условной силы, противонаправленной устремлениям русских героев-князей. Она дает сябя знать во всех без исключения фрагментах употребления лексемы в «Слове»: «Чръныя тучя съ моря... хотять прикрыти д солнца... на рекъ на Каяль»; «Съ тоя же Каялы... ко святьй Софіи къ Кіеву»; «Ту ся брата разлучиста на брезъ... Каялы»; Игорь вместо победы и бо-

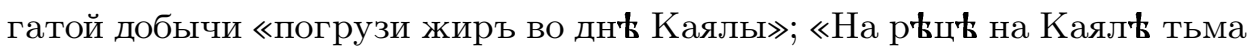
свłть покрыла» ${ }^{25}$. «Каялу» в плаче Ярославны многие исследователи соотносят с представлением о мертвой воде русского фольклора ${ }^{26}$.

Этот же психо-лингвистический принцип организует и поэтический синтаксис в Ипатьевской летописи. Ядром здесь является словосочетание «наведе на ня/ны». Оно присутствует в каждой из трех синтагм и всюду дополняется пре- и постпозитивно соответственно единомотивно: от позитива к негативу:

[в годину отпущения и милости] Наведе на ня господь гнњвъ свои, в радости мњсто наведе на ны плачь

и

во веселье мњсто [наведе на ны] желю на рtъц Каялы ${ }^{27}$.

23 Сказания и повести о Куликовской битве, Ленинград 1982, с. 7.

24 Там же, с. 8.

25 Энциклопедия «Слова о полку Игореве»..., т. 1, с. 10, 11.

26 Там же, т. 4, с. 110.

27 Словарь-справочник «лова о полку Игореве».., вып. 2, с. 179. 
В третьей части фразы, когда уже в двух предыдущих основные смысловые и стилистические акценты вполне определены и выделены, автор являет эллиптическое стяжение. На месте введенного нами «наведе на ны» в древнерусском тексте следовало бы поставить тире.

Принимая во внимание, что слово «гнывъ» имеет здесь очевидное значение 'кара, наказание' 28 , мы можем говорить о явленности в данном случае фигуры стилистической симметрии. Она описана Д. С. Лихачевым следующим образом: Об одном и том же в сходной синтаксической форме говорится дваждь; это как бы некоторая остановка в повествовании, повторение близкой мьили, близкого суждения, или новое суждение, но о том же самом явлении. Второй член симметрии говорит о том же, о чем и первыи член, но в других словах и другими образами. Мьсль варьируется, но сущность ее не меняется ${ }^{29}$. Определяя виды этой поэтической фигуры, глубокую архаичность истоков, связь с библейскими текстами и т. д., ученый, однако, приводит только парные примеры ее классического проявления. Мы же имеем в рассматриваемом фрагменте не усложненную и не растворенную в близких стилистических явлениях, а безукоризненно организованную триединую параллельную симметрию. А потому можем с большей уверенностью, чем в отношении двучастной, говорить о лексическом содержании каждого из членов, т. к. каждый из них помогает понять другой Воспользовавшись этим положением и опытом ученого по идентификации редких слов можем утверждать в отношении «Каялы», что его непосредственная смысловая связь с гипотетическим этимоном 'скалистый' для летописца XII века утрачена. «Каялы» помещено в одном полюсе симметрии с «господь гнывъ свои» («гнывъ»-«1. 'гнев', 'кара, наказание', 3. 'неистовство'»31; «плачь» - «1. 'плач; - 'выражение горя,

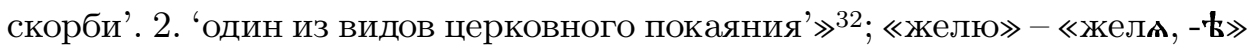
- 'печаль', 'скорбь'33, т.е. находится в их семантическом поле, «говорит об одном и том же»34. Объединяющая их семантика имеет в данном случае «наводящее значение» 35 и потому «Каялы» недвусмысленно

28 Словарь древнерусского языка (XI-XIV вв.): В 10 томах, Москва 1989, т. 2, с. 339.

29 Д. Лихачев, Поэтика древнерусской литературь, Москва 1979, с. 169.

30 Там же, с. 170.

31 Словарь древнерусского языка (XI-XIV вв.)..,, т. 2, с. 339.

32 http://onlineslovari.com/slovar_drevnerussrjgo_jazyka_w/page/placy.9729

33 Словарь древнерусского языка (XI-XIV вв.)..., т. 3, с. 244.

34 Д. Лихачев, Поэтика древнерусской литературыљ.., с. 171.

35 Там же. 
комбинируется с глаголом «кагати» в значении 'порицать, осуждать'36. Обращает на себя внимание, что данное словоупотребление представлено редко: составители «Словаря древнерусского языка (XI-XIV вв.)» зафиксировали их всего два, и одно из них, наиболее близкое к интересующему нас, - у прилагательного «кагазныи» 'относящийся к церковному покаянию, епитимии'37. (Но значительно обильнее примеры, в которых это лексическое гнездо выступает со значением 'раскаяние' - «кагазнь» - 3, «каганию»-3, а также 'каяться; исповедоваться в грехах', 'приносить церковное покаяние', 'раскаиваться в чем-л., жалеть о чем-л.' - «кагатисл» - 251 и др. $\left.{ }^{38}\right)$. Так, мы наблюдаем, что смысловая связь «Каял(-ы)» с глаголом «каяти» во всей многоаспектности его семантического гнезда для составителя текста летописи и потенциального читателя закреплена вполне, и религиозная «подсветка» этого комплекса значений - не менее отчетлива.

Предложенное толкование и структурирование текста, на наш взгляд, поддерживается и слабой троекратной рифмой: это «свои́»«ны», которые в свою очередь как бы «вызывают к жизни» форму «Каяль́». Рифма здесь дополнительно скрепляет смысл высказывания, опоясывает и завершает фигуру тропа. Введение в текст альтернативного варианта «Каяль» воздействовало бы на поэтику фрагмента деструктивно: не только не продлевало означенный ряд, но формировало

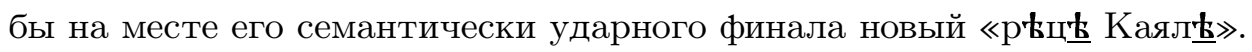

Полагаем, что не без влияния этого обстоятельства авторский коллектив «Энциклопедии «Слова о полку Игореве»», хотя и ссылаясь лишь на мнение сторонников тюркской этимологии, в вариантном реестровом слове констатировал ударение «Каяла (Каялы́)» как «первоначально несклоняемой форме слова в Ипат. лет.» 39 . При отчетливом повышении внимания современной науки к средним векам, выходе в свет целого ряда работ, в том числе белорусских медиевистов (Л. В. Левшун, И. В. Саверченко, В. А. Чемерицкий, А. А. Шелемова и др.), нам не удалось отметить в исследовательской литературе рассмотрения данного фрагмента в означенном аспекте либо анализа сходной структуры высказывания как самостоятельного явления поэтики. Ведь в летописях преимущественно и справедливо отмечаются прежде всего жанровые доминанты: характер констатации единичных истори-

36 Словарь древнерусского языка (XI-XIV вв.).., т. 4, с. 206-207.

37 Там же, с. 206.

38 Там же, с. 206-207.

39 Энциклопедия «Слова о полку Игореве»..., т. 3, с. 31-34. 
ческих фактов, идейно-политических интенций составителей, а в сфере стилистики - комплекс традиционных формул синтаксических и лексических конструкций. Сюжетно организованное повествование в противовес погодным лаконичным информациям, свежие достоверные детали событий, приемы поэтики неделового стиля, а тем более развернутые риторические фигуры как спорадические явления беллетризации изложения - здесь редки. А для повести 1185 года по Ипатьевскому варианту традиционно среди композиционных звеньев выделялась самая пространная молитва Игоря, где автор проявил себя как знаток книжной риторики, мастерски владеющий ее приемами, которые с особой силой явлены в знаменитой покаянной речи ${ }^{40}$. Возможно, это обстоятельство - сосредоточенность на последующем тексте - сделало «невидимой» в XX веке выделенную структуру высказывания. Даже в самых авторитетных изданиях она приведена такой длины, которая не является эстетически значимой, не позволяет квалифицировать ее в качестве сообщения для декодирования ${ }^{41}$. Более того, при переводе анализируемой фразы на русский язык О. В. Твороговым нивелируется организующая роль «наведе на нж/ны» как центра синтаксической композиции. В противовес древнему источнику выражение заменяется двумя разными для каждого периода синонимичными словосочетаниями «низвел на нас», «обрек нас на», что далеко не компенсируется справедливой постановкой тире в третьем периоде. Представляется также не совсем удачным здесь по причине силлепсиса и введение дополнительного, четвертого предлога «на» (при трех в источнике) в положении смежности со словосочетанием «на реке Каялы» ${ }^{42}$. Ведь по народно-поэтической традиции и согласно разговорной речи оборот «река + ее название» подразумевал повторение предлога «на» перед онимом. Сравним:

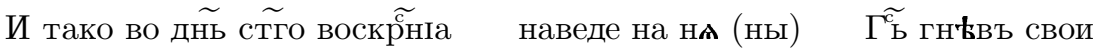
в радости м'ссто наведе на ны плачь

и

во веселье (въ веселіа) м'ксто

желю на рнць Кагалы ${ }^{43}$;

40 А. Пауткин, Беседы с летописцем. Поэтика раннего русского летописания, Москва 2002, с. 93.

41 См.: Словарь-справочник «Слова о полку Игореве»..., вып. 2, с. 179; Словарь древнерусского языка (XI-XIV вв.)..., т. 3, с. 244; Энииклопедия «Слова о полку Игореве»..., т. 3, с. 31 .

42 Памятники литературы Древней Руси: ХІІ век, Москва 1980, с. 357.

43 Полное собрание русских летописей, СПб. 1908, т. 2, л. 224 об. Здесь и далее в цитатах из летописи некоторые разночтения списков приводятся в скобках. 
И так в день святого воскресения низвел на нас господь гнев свой, вместо радости обрек нас на плач, и вместо веселья - на горе на реке Каялы ${ }^{44}$.

В Ипатьевской летописи эта замечательная фраза обрывает пространное, четкое и конкретное описание боя (и к нему уже автор не возвращается): «Всеволодъ же толма бившесл. гако и шроужыа в роукоу его не доста. и быахоу бо сл идоуще в кроугъ. при езерł...»45. Созданная в ином стилистическом регистре, она звучит как самостоятельная прелюдия, открывая собой в десять раз (построчно) больший ее отрезок текста - «молитву» Игоря. Последняя начинается дополнительными вводными словами: «реч бо дыи Игорь...», где церковнославянское «дњи (деи)» презетует модальность: значение неабсолютной достоверности, предположительности, 'разве'46. Эти покаянные раздумья и глубокий вздох, вопль отчаянья с надеждой на Божью милость заменяют собой, очевидно, очень болезненное для автора описание разгрома. Следующая информация - уже о конкретных судьбах пленных соратников Игоря.

Многие авторитетные исследователи не без основания видят в такой неоднородности компилятивность, прежде всего следы влияния разных протографов. («Основанием» в данном случае надо признать то неприятное обстоятельство, которое констатировал еще в 1985 году, открывая свое исследование «Летописный свод Игоря Святославича и «Слово о полку Игореве»», Д. С. Лихачев: История Ипатьевской летописи - важнейшей для изучения летописания ХІІ в. - почти не исследована ${ }^{47}$. С той поры ряд значительных идейных и текстологических наблюдений в публикациях Н. С. Демковой, Е. М. Добрушкина, А. А. Зимина, А. Г. Кузьмина, Б. А. Рыбакова, Л. В. Соколовой, В. Ю. Франчука, Б. И. Яценко были посвящены решению смежных, но все же иных проблем. В историографии же Ипатьевской летописи стало возможным говорить о целенаправленном изучении поэтики данного произведения лишь на рубеже XX-XXI веков). Однако трудно отрицать в этой предположительной эклектике различных источников (для древности, отличительно от нового времени, этот термин

\footnotetext{
44 Памятники литературь Древней Руси: ХІІ век.., с. 357.

45 Полное собрание русских летописей, т. 2, л. 224 об.

46 Старославянский словарь (по рукописям X-ХI веков), Москва 1994, с. 205; Ср.: В. Франчук, Формирование текста летописного рассказа Ипатьевской летописи о походе князя Игоря на половчев в 1185 г., [в:] ТОДРЛ т. 57, 2006, с. 89-90.

47 Д. Лихачев, «Слово о полку Игореве» и культура его времени, Ленинград 1985, c. 145 .
} 
не имел негативной окраски) внутреннюю упорядоченность, ассоциативность авторского мышления - поэтическую цельность и единство. Мы рисковали бы априори изолироваться от перспективной и плодотворной сосредоточенности наблюдений над приемами высокохудожественной организации текста. Что для данного фрагмента, возможно, и произошло в исследовании А. А. Пауткина «Древнерусские летописи XI-XIII вв.: Вопросы поэтики». Автор «отсек» во фразе акцентные идейно-стилистические словосочетания начала и конца «и тако во диь

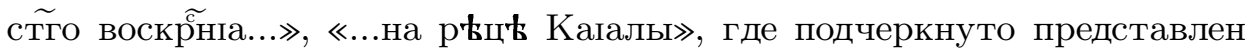
антагонизм состояния до и после сражения. В том виде, как высказывание извлечено из летописи «наведе на ня Г (оспод)ь гнывъ свои в радости мłсто наведе на ны плачь и во веселье мłсто желю», оно справедливо расценено как «авторское замечание», в котором отмечена лишь печаль, разлитая... в строке $e^{48}$. Хотя в противоположность этому случаю многие другие текстологические параллели для повести 1185 года с объемными и тщательно составленными описаниями междоусобиц XII века (например, в работах А. А. Пауткина для 1151 года и др.) позволяют утверждать, что нигде при порицании котор не упоминалась в качестве отрицательной оценочной характеристики этих столкновений река Каяла но, конечно же, существовало немало героев-князей, которые, по мнению летописцев, должны были бы пройти сквозь горнило порицания-наказания и раскаяния в своих поступках.

Выделенная нами поэтическая фигура с семантически акцентным словом «Каялы», как увидим далее, оказывает организующее, центростремительное влияние на весь текст 1185 года. В качестве стержневого явления она выступает в модификациях, корреспондирующих со смыслом и стилистикой окружающих повествовательных полей. Проследим логику этих эстетических взаимодействий.

Накопленный на сегодняшний день опыт изучения летописей позволяет говорить об излишней категоричности широко распространенного мнения о стратификации сюжетно-тематической информации. В частности, в Ипатьевском списке наблюдаются, кроме уже отмеченных, значительные отступления от этого положения. Например, подобно близким нескольким предшествующим годам, все сведения, объединенные датой «въ льто 6693» (новеллы о победе над половцами Святослава Всеволодовича и Рюрика Ростиславича, о мотивировке неучастия в походе его брата Ярослава Черниговского и Игоря Святославича,

48 А. Пауткин, Беседы с летописцем..., Москва 2002, с. 90. 
успешном военном предприятии той же весной Святослава Киевского и выступлении, организованном Игорем Святославичем) подчеркнуто скреплены единой мыслью об адекватности / неадекватности конкретных поступков русских князей Божьему промыслу, направленному на возвеличение Руси. Этот императив в форме публицистической декларации открывает годовую запись, дважды явлен в сюжетно ударных фрагментах и завершает собой хронологический раздел: «Съдыга Гг сппне. свое. дасть побњдоу голзема Роускыма...»49, «и тако во днъ...

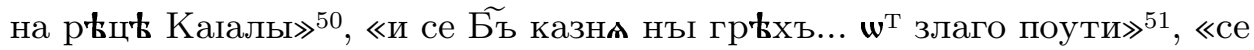

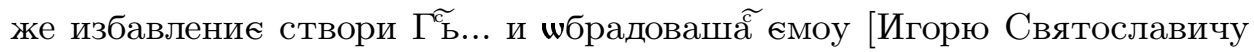
- Л.3.]... ІАрослав же шбрадовасж емоу и помощь ємоу да. ... и радъ бы $\widetilde{\mathrm{I}}$ ємоу Стославъ. такъ же и Рюрикъ сватъ єго»52.

Своим не только идейным, но и стилистическим, мотивным подобием эти фразы скрепляют последовательные, но различные информационные пласты в развивающуюся целостность и демонстрируют связь с ней собственных инвариантов. Так, начальный блок года ука-

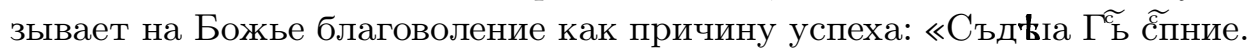
свое. дасть побњдоу кнжзема Роускыма. Стславоу Всеводичю (всеволо-

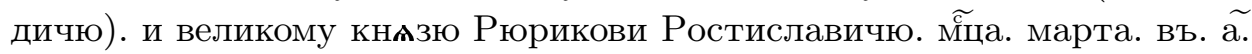
дег оудавъша (оугадавше/оув ста по немь...»53. Он как первоаккорд открывает собой серию последовательных по времени и резонирующих позитивных сюжетных линий: «поидоша когождо во свогаси (кождо въ своаси). славлще Ба...» ${ }^{54}$, «не

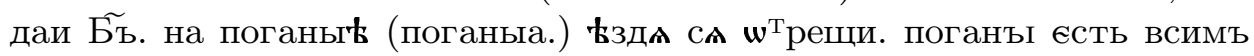

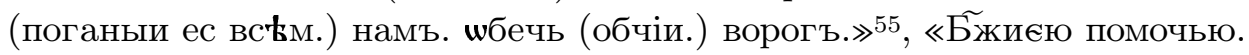
(приб. ти.) взАша вежы Половецьк'и. (половецкіа.) ${ }^{56}$ и т.д.

Приведенные примеры мы считаем возможным рассматривать не только в традиционном ключе интенции религиозности летописца, но и как важный и часто используемый, даже можно сказать, «заглавный» элемент поэтики. (По данным «Словаря древнерусского языка (XI-XIV вв.)», слово «Богъ» употреблено в письменности означенного

49 Полное собрание русских летописей.., т. 2, л. 222 об.

50 Там же, л. 224 об.

51 Там же, л. 226.

52 Там же, л. 227.

53 Полное собрание русских летописей.., т. 2, л. 222 об.

54 Там же.

55 Там же, л. 223.

56 Там же. 
в заглавии словаря периода более 11000 раз, «Божии»- примерно 5000, «Божьствьныи» - примерно 2000 из общего числа около 2000000 цитат ${ }^{57}$.) Такой ее инструмент, который определяет явленность многих других, в том числе и типологически близкое функционирование того, который мы рассмотрим ниже.

Исследователи не раз отмечали «исключительное богатство разнообразными хронологическими уточнениями», «разработанную систему хронологических подробностей» в описании Игорева похода ${ }^{58}$. Однако, по нашему мнению, здесь имеет смысл не изолировать данную повесть от суммарной картины описания экспансии 6693 года, а говорить о большем разнообразии и частотной насыщенности этого текста временными факторами как жанрообразующими, а также об их стилеобразующей роли для отдельных тематических зон. Даже отвлекаясь от обилия глагольных форм, которые грамматически фиксируют взаимопоследовательность действий (но конечно же, не исключая его мощного организующего информационно-эмоционального влияния на читателя летописи) можно говорить об особенно высокой численности темпоральных обозначений в области лексики - их около восьмидесяти. При этом, как увидим ниже, подавляющее большинство показателей и разнообразных их форм представлены в позитивной содержательной зоне: от начала годовой записи до пленения Игоря, затем от побега и до конца повести. Здесь они отличаются семантическим разнообразием, структурной усложненностью: название поры года, месяца, числа месяца, дня недели, части суток, продолжительности события, соотнесенности с предшествующим или датой христианского календаря. Это: «М پа. марта. въ. а. деъь», «потом же гада», «в четвергъ», «в неднлю», «пе-

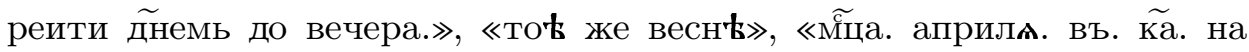
самыи великъ днг. тогда же» ${ }^{5}$. И затем в повествовании о собственно Игоревом походе: «В то же времх С тославичь. Игорь вноукъ Шлговъ.

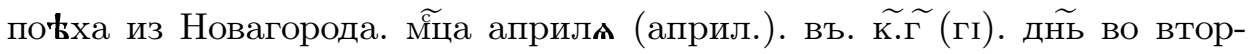

57 Словарь древнерусского языка (XI-XIV вв.)..., т. 1, с. 5, 274, 276, 280.

58 См. напр.: А. Пауткин, Летописная повесть о походе 1185 года Игоря Святославича на половчев ( $к$ проблеме художественности, "Филологические науки" 1985, № 2, с. 27. Автор пишет: Приведем хронологические данные (всего 27! - Л.3.) летописной повести, разделив их на три группь. Первая - точнье обозначения времени действия... Вторая - указания на продолжительность действия... K третьей группе... обороты,... для показа одновременных событий, обозначения связи прошлого и настоящего и для соединения отдельньх эпизодов воедино (соответственно 10, 7 и 6 обозначений - Л.З.). Там же, с. 27-28.

59 Там же. 
никъ», «в годъ вечернии.»60, «два дни.», «тоу же»- 'тогда', «не наше єсть верема.», «чересъ ночь.», «заоутра же в плтькоу наставшоу. во

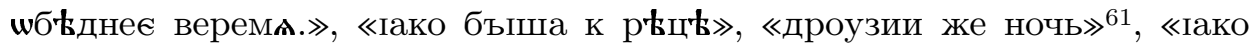
собрашасл», «нын' же», «чересь ночь.», «заоутра. по насъ.», «нын'

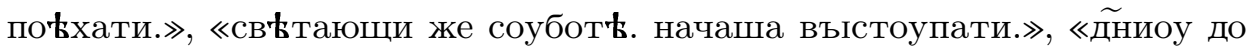

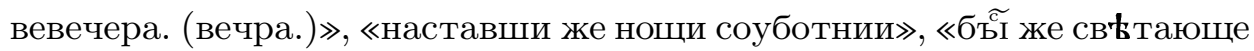

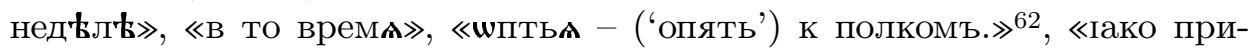
ближисл», «тоу - 'время и место' гаша.»63.

Хронист тем самым выражает стремление к точности и скрупулезности изложения, социально-идеологической подсветке развития событий. Этот стиль достигает своеобразного апогея в описании завершающего периода Игоревой битвы: «и тако биша̃ крњпко тоу. дниноу до вевечера (вечра). и мнозии ранении. мертви быша. в полкохъ Роускй (роускых.). наставши же нощи соуботнии и поидоша бьючисл.

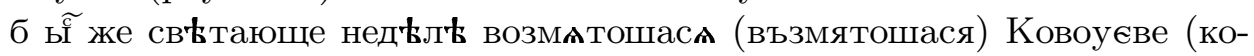
уевъ)...» 64 . Затем наблюдаем явление необычное и даже парадоксальное для художественной логики летописи: событийный и временной ряды лишаются динамики вербального развития, а концентрируются в формуле стилистического параллелизма. В ней снова сообщается о только что случившемся и дублируется уже приведенный ранее темпоральный показатель. Ведь о том, в какой день наступило поражение, читаем дважды: «бы

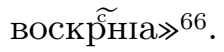

Вся начальная часть выделенной нами выше поэтической фигуры как бы подчеркнуто направлена на реализацию значения времени. Здесь лексический показатель дня недели, связанный с религиозным событием вынесен в логически ударную позицию начала предложения. Он обособлен и выделен в этом положении; предположительно, именно с этой же целью несколько «неожиданно» для всей структуры, из левой, позитивной части в первой параллели слово «ГГ⿱宀㠯 » перемещено в правую, негативную. При этом оставшийся член стал максимально

\footnotetext{
60 Полное собрание русских летописей.., т. 2, л. 223.

61 Там же, л. 223 об.

62 Там же, л. 224.

63 Там же, л. 224 об.

64 Там же, л. 224.

65 Там же.

66 Там же, л. 224 об.
} 
включен в вертикаль системы как начальный компонент ситуативных

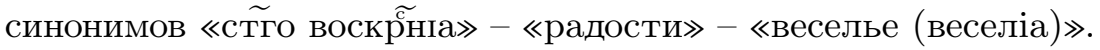

Как уже отмечалось в трудах по исторической лингвистике с опорой на древнееврейские, древнегреческие источники, Синайский глаголический текст псалтыри XI века, два последних слова, бесспорно, являются синонимами ${ }^{67}$. Прирастание же этого ряда начальным членом теоретически опирается на наблюдения Е. М. Верещагина о семантически дополняющих друг друга словах: Не являясь синонимами, тем не менее принадлежат $\kappa$ одной и той же тематической группе лексики и довольно часто в контексте выступают с нейтрализачией отличий друг от друга, т.е. практически обозначают одно $u$ то же $e^{68}$. Ученый при этом справедливо отмечает: прием параллелизма подсказьвает, что и оставшиеся слова в совпадаюших синтаксических конструкииях должнь быть близки друг другу. Тематические слова сохраняют определенные характеристики синонимов - они связаны по смьслу и способны $\kappa$ взаимозамене, но отличаются от них степенью представленности того и другого качества ${ }^{69}$. В нашем случае акцентный временной показатель «во днъ» тогда сопрягается с «в... мłсто», «во... мłсто», где последняя лексема выступает в своей наиболее историческидавней функции - как заменитель любого другого апеллятива с конкретным значением. Таким образом, в этой взаимосвязи «мысто», употребленное дважды, обретает несколько даже подчеркнутую темпоральную коннотацию, реализует свое значение «6. 'время, пора'»70.

Одновременно в антонимическом соотношении левого и правого столбца второй и третьей параллели мы наблюдаем более позднюю переходную смысловую конструкцию «в... мҺсто» $\rightarrow$ 'вместо': «в радости мłсто»- - «плачь», «во веселье (веселіа) м'ссто»-«желю». Заключительный член традиционных в таких случаях тернарных позиций связан с реализацией доминирующего значения «мњсто»- «1. 'определенное пространство, на котором что-л. происходит, находится'»71. Оно проявляется в процессе семантического «антагонизма» левой и правой

67 См., напр.: Е. Верещагин, Прием параллелизма в Псалтыри и выляление смысловых связей между словами первого литературного языка славян, "Советское славяноведение" 1975, № 2, с. 66.

68 Там же.

69 Там же.

70 http://onlineslovari.com/slovar_drevnerussrjgo_jazyka_w/page/msno.4140.

71 Там же. 
частей третьей параллели, реализуя лишь указание на некую территорию. Затем дополнительно укрепляется в четвертой строке благодаря сопоставлению с указанием на конкретное место действия «на рłцł Кагалы». При этом «мњсто» (левый столбец) противостоит четкости указания на реалию в собственно географическом ониме «Кагалы», чем дополнительно стилистически актуализирует эту четкость и одновременно обогащает слово-партнер в этом сопряжении некоторыми своими коннотациями. Последние берут свой «исток» во вполне временно́й по своему смыслу начальной части первой параллели «во день». Поэтому можно утверждать, что в искомом значении проблемного «Кагалы» сочетается указание на место действия с выразительной семантикой времени: 1) синонимичные в этом отношении речения-антонимы «во дег

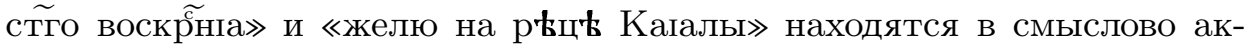
центных позициях, взаимо притягиваются и скрепляют собой, начиная и заключая, фразу; 2) во втором словосочетании указание на конкретное время в искомом «на рłцt Кагалы» непременно подразумевается еще и потому, что битва на этой реке отмечалась в истории Руси лишь однажды, воспринималась как достопамятная. Так, вся организация высказывания целеустремленно формирует становление темпоральной коннотации референта.

В дополнение к сказанному хотелось бы подчеркнуть, что текст выделенной поэтической фигуры не просто аскетичен, а чрезвычайно беден в информационно-логическом плане. Ведь о переломе в развитии военных действий от успеха к поражению мы уже знали в подробностях, о том, когда это произошло - тоже, о Божьей воле информация приводилась неоднократно от момента выступления в поход до пространной молитвы Игоря («таины Бйа же никто не вњсть...»72, «но

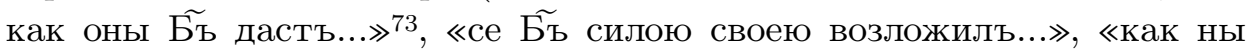

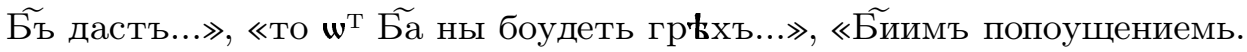
оулзвиша Игорж в роукоу» ${ }^{74}$ ). Таким образом, здесь единственный лексический показатель представляющий новое знание о событиях 1185 года - есть словосочетание «на рłцł Кагалы». Оно как бы венчает собой эту стилистическую фигуру, не утратив традиционного локативного смысла и одновременно манифестируя актуальный, которым обогатилось именно в данном стилистическом образовании - темпоральный.

\footnotetext{
72 Полное собрание русских летописей.., т. 2, л. 223, 223 об.

73 Там же, л. 223 об.

74 Там же, л. 224.
} 
(Именно это значение слова «Каяла» будет активно воспринято и эстетически компрессировано позднее в «Задонщине» ${ }^{75}$ ).

Рассматривая в филиационном плане важнейшее и типичное для летописи линейное движение времени в его лексической данности, отмечаем, что оно значительно обедняется. По сравнению с предшествующим описательным блоком (от начала погодной записи до пленения Игоря) лишается прежнего обилия, разнообразия, развернутости формул, выполняя лишь задачу регламентировать на письме последовательность произошедшего. Приведем все отмеченные лексемы темпоральной семантики: «тогда», «тогда», «нын-њ», «ныны», «ныны»76, «де «на все льто.», «Іако возворотисл», «Іако приде», «во ть годъ.», «ныны», «по сем же»78, «николи», «по сем же», «льтовати», «нын $\mathbf{k} »$, «всь (вес) дег. немогл中», «шплть» 80 . Так время в своей социумно значимой конкретике здесь как бы сходит на нет, а далее на протяжении 20 строк печатного текста нам не удалось отметить ни одного лексического показателя его динамики. (Единственная такого рода лакуна в изучаемом хронологическом объеме!) Пиком этого периода, подобно преждеописанному, является также завершающее его стилистически и синтаксически синонимичное построение:

75 Любопытно отметить, что Д. С. Лихачев в своей статье «Пирогощая «Слова о полку Игореве» при цитировании Ипатьевского отрезка поддерживает пунктуацию, которая как нельзя более точно свидетельствует об итоговом, обобщающем характере речения (первая запятая и двоеточие) и семантически акцентном «на реце Каялы» (предшествующая запятая). Ученый фиксирует: И тако, во день святаго Воскресения, наведе на ня Господь гнев свой: в радости место наведе на ны плачь, и во веселье место желю, на реце Каяль (Д. Лихачев, «Слово о полку Игореве» и культура его времени, Ленинград 1978, с. 213; Д. Лихачев, «Слово о полку Игореве» и культура его времени, Ленинград 1985, с. 272).

76 Полное собрание русских летописей.., т. 2, л. 224 об.

77 Как справедливо отметил В. Ю. Франчук относительно молитвы Игоря, из которой выписаны эти показатели, она построена на антитезе прошлого и настоящего: в прошлом - грех Игоря; в настоящем - следствие этого греха... Последовательность событий, которые как будто происходили, можно представить лишь приблизительно... Значение прошлого времени усиливается повторением наречия тогда... Впечатление усиливают простье формь глагола в прошедшем времени (аорист, имперфект)... О времени произнесения молитвы свидетельствует четьрежды повторенное наречие нынп... Один раз подчеркивает это значение наречие днесь (В. Франчук, Формирование текста летописного рассказа Ипатьевской летописи..., с. 87-88).

78 Полное собрание русских летописей.., т. 2, л. 225.

79 Там же, л. 225 об.

80 Там же, л. 226. 


\section{Се $\widetilde{\text { ъ }}$ казня ны (нас) грłхь ради нашихъ (за грқхы наша) наведе на ны но насъ казнж. и шбращага ны к покаганью да быхом сл востлгноули (въстягноули.) $\boldsymbol{w}^{\mathrm{T}}$ злыхъ свой $\widetilde{\widetilde{\mathbf{k}}}$ длъ.}

и симъ казнить ны (казнит нас), (и сам нас казнит) нахожениемь (нахожденіем) поганыхь да некли (не како ли) смиривошесл воспоманемьса (въспомянемся) $\boldsymbol{w}^{\mathrm{T}}$ злаго поути ${ }^{81}$.

Эта фигура своей структурой и семантикой, очевидно, легко корреспондировала в сознании писца-создателя, скрипторов и читателей с предыдущим модулем. Она воспринималась как симптоматичная вариация, «правка» уже заданной прежде системы, но с иной степенью формализованности в новых смысловых текстовых условиях: 1) усовершенствования и четкости реализации; 2) адекватности стилистическому и содержательному полю повествования, которое она итожит и замыкает собой.

В соответствии с первым: оним божества перемещен из правой, негативной части фигуры в левую - место явленности позитива. При этом она как бы подчеркнуто санирована в теологическом плане: из нее удалены все лексические показатели, имеющие предметно-логические связи с земной, мирской жизнью. Выражение «во дег стго воскг̃ нга» опущено, а слово «Гᄃ Б) (в контексте 'Бог'), которое было общеупотребительно не только в речениях о Всевышнем, но и 'владельце, хозяине', 'господине, повелителе' или вообще как «форма почтительного обращения 82 , заменено лексемой с единственным основным значением -

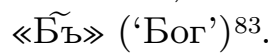

Таким образом, перед нами усложненная модель итеративности, где «се Б泣 четырежды употребляется-подразумевается в смыслоударной позиции левого «положительного» столбца; стержневое связующее сочетание - «казня пу», «наведе на ны», «но насъ казня. и шбращага ны», «казнить ны». А в правой части этот катрен имеет перекрестное синонимическое сцепление: «грłхъ ради нашихъ»- «к покаганью...»; «поганыг...»- «нахожениемь поганыхъ...». Здесь после лаконичного обозначения в первом ряду структурного показателя компоненты

\footnotetext{
81 Там же.

82 Словарь древнерусского языка (XI-XIV вв.).., т. 2, с. 367-368.

83 Там же, т. 1 , с. 5, 274-275.
} 
2-4 рядов имеют к основным в фигуре словосочетаниям распространенные пояснения: «не аки милоуга ихъ»; «да быхом сл востлгноули $\boldsymbol{w}^{\mathrm{T}}$ злыхъ сво $\widetilde{\mathbf{x}^{\mathbf{x}}}$ дтлъ»; «да некли смиривошесл воспомлнемьсл $\boldsymbol{w}^{\mathrm{T}}$ злаго поути». Они указывают на сопутствующие обстоятельства антагонистических отношений русских с половцами, причинность и векторность выхода из нее. Возникшая в связи с этим многословием «размытость» модели стилистически вполне согласуется с характером летописного повествования, «курируемого» этой формулой. Прежде всего это относится к нечеткости указаний на время и даже полному отсутствию календарных дат (разумеется, кроме статейного общезаголовочного) при рассказе о событиях на территории Руси.

Описанные отличия обоих комплексов (сообщение + формула) имеют свой общий как бы бренд - слово «Каялы». Во втором явлении фигуры оно, по содержанию близкое концепту, показательно отсутствует, довершая тем родственность / отличие двух фрагментов и дополнительно актуализируя временной коннотативный показатель своего онимного семантического поля. И лексические импульсы времени в нем как бы раскрепощаются от стилистических ограничений, обретают прежнее богатство форм, свойственное вступительной части ипатьевской Игориды: «тоть годъ» $84 ;$ «дольго», «исперва», «тогда», «нын $\mathbf{k} »$, «времл таково.», «преже», «в дегь и в нощь.», «веремл таково», «в заходъ слина.», «времл», «при вечер'ъ» 85 , «в плтокъ в вечерґ», «а̃. денъ.» 86 . Этот завершающий отрезок 1185 года семантически и стилистически уже не нуждается в напряженных конвергенциях, антагонистических кодах фигур. Теперь автор говорит о примирении человеческой воли указующему Божьему императиву: Игорь молится, послушный всевышней воле (но не рыцарской логике) бежит из плена. И поэтому наступает гармония, а с ней - позитивная перспектива жизни на Руси, реализуемая во взаимопомощи князей и всеобщем чувстве радости: «Се же избавление створи Г⿳宀 в в плтокъ в вечерł... иде во свои Новъгородъ и шбрадоваша̃ емоу, из Новагорода иде ко брату ІАрославоу к Черниговоу. помощи просл... ІАрослав же шбрадовасж емоу и помощь емоу да. шбњща. Игорь... $\mathbf{k x a ~ к о ~ К и є в о у ~ к ~ в е л и к о м о у . ~}$ кнзю Стославоу. и радъ бь єго»87. Так, мы наблюдаем здесь развязку, снятие кульминации идей-

84 Полное собрание русских летописей.., т. 2, л. 226.

85 Там же, л. 226 об.

86 Там же, л. 227.

87 Там же. 
но-стилистического напряжения и сюжетного конфликта с заявленным в них своеобразным эпицентром негатива - «Каялы».

Полагаем, на этом основании есть возможность утверждать, что как имя собственное гидроним «Каялы» имел некоторую реальную привязку, реку-референт с, возможно, паронимическим наименованием, которое в сознании носителей русского языка конца XII века ассоциировалось с религиозно-нравственной, идейно-политической, исторической и т.д. оценкой конкретного явления общественной жизни. Под влиянием, безусловно, тенденциозного литературного освещения произошедшее обретало в осмыслении современников символическе содержание, сопрягало звуковую оболочку чужеземного онима с по-христиански развитой многоаспектностью семантического поля глагола «каяти».

На основе изложенного предпримем ряд суждений о грамматических характеристиках и происхождении закрепленной во всех вариантах данного хронологического повествования формы «Каялы».

С текстом Игориды в Ипатьевской летописи соприкасались скрипторы едва ли не из всех важнейших центров Древней Руси: Киев, Переяславль-Южный, Ростов, Суздаль и Владимир, Чернигов, Галичь, Волынь и т.д. Наиболее подробное описание похода связывают с южными Киевским и Галицко-Волынским сводами, которые затем подверглись существенной переработке. Достаточно напомнить, что даже годовая сетка в последнюю была привнесена псковским редактором XV века. Поэтому бытование и эволюция интересующего нас фрагмента протекала в условиях речевой нестабильности, достаточно пестрой картины говоров. Это обстоятельство не могло не сказаться на реализации грамматических норм и в частности флексий родительного и предложного (местного) падежей склонения существительных женского рода на «-а», в системе которых возможно представить оним «Каялы».

Опираясь на общепринятое положение о консервативности диалектных показателей, в отношении преимущественно интересующих нас Псковских ${ }^{88}$, обратимся к данным современной диалектологии, как наиболее скрупулезным и систематизированным.

Подробный анализ склонения на «-а» по русским говорам середины ХХ века позволил сделать следующие выводы. 1) В отношении родительного падежа дифференциация в употреблении окончаний -и (-ы)

88 См. об этом, напр.: С. Николаев, $K$ истории племенного диалекта кривичей, "Советское славяноведение" 1990, № 4. 
и -е не выдерживается, «напротив, можно с уверенностью сказать, что во многих говорах она существует лишь как тенденция» ${ }^{89}$. 2) В отношении совпадения флексий родительного и предложного: $B$ mex говорах, где распространено окончание -е в родительном падеже, это же окончание как правило имеет место и в дательном-предложном падежах, но поскольку в родительном падеже окончание -е чаще всего употребляется наряду с окончанием -и (-ь), а для дательного и предложного падежей большинство говоров имеет при этом только окончание -е, то полного совпадения родительного падежа с дательным и предложным в этих говорах обычно нет, а есть лишь ослабление их противопоставленности ${ }^{90}$.

Ввиду такой «размытости» общей картины перейдем к рассмотрению отдельных, более узких ее ареалов. Прежде всего к южным границам северного наречия, где отмечалась локализация Ипатьевского списка начиная с XV века. Лингвисты выделяют здесь охарактеризованное как двучленное и основополагающее грамматическое явление окончание -ьл в форме родительного падежа единственного числа существительных женского рода с окончанием - $a$ и твердой основой ${ }^{91}$. Более детальная территориальная привязка - выделение северо-западной диалектной зоны - позволяет говорить о распространении форм дательного-предложного падежей единственного числа с окончанием - $u(-b l)$ у существительных женского рода на - $a$ с твердой и мягкой основой $^{92}$. Что же касается непосредственно псковской группы (Западные среднерусские акающие говоры), то здесь среди ряда в основном характерных для этой группь явлений констатировано распространение форм род п. ед. ч. с окончанием -е, у существительньх ж.р. с окончанием - а и твердой основой, употребляемьх как в сочетании с различными предлогами, так и в беспредложных конструкииях ${ }^{93}$.

Заметим при этом, что А. А. Зализняк в своей книге «Слово о полку Игореве»: Взгляд лингвиста», анализируя местные языковые характеристики «Слова», особо выделяет позицию дательного и местного падежей женского рода склонения на «-а», представленные флексией на «-ы». Для ученого не существует сомнений, что такие формы,

89 Русская диалектология, под ред. Р. И. Аванесова и В. Г. Орловой, Москва 1964, c. 104 .

90 Там же, с. 105.

91 Там же, с. 237.

92 Там же, с. 248.

93 Там же, с. 288, 289. 
как «к Москвы», «не по псковскои старины» дательного, единственного числа и «на Москвы» местного, единственного из Строевского списка Псковской 3-й летописи, а также «к Донцю рłкы» дательного единственного из Ипатьевской летописи - диалектного происхождения, где слова женского рода в данных позициях имеют окончание «-ы» ${ }^{94}$. На наш взгляд, «к Донцю рtкы» и «на рtцł Каялы», использованные в едином повествовании о сражении Игоря 1185 года ${ }^{95}$ являют собой близкие синтаксические формулы, отразившие взаимовлияние устной народно-поэтической и письменной стилистики. Последняя не требовала повторения предлога одновременно с более четкой определенностью, известной стабильностью флексивно-падежных форм. Самая эта «расшатанность» стилистической ситуации с учетом начала утраты «中» как специфического славянского звука в XII веке манифестирует своеобразную свободу творчества автора-повествователя, стремившегося подчеркнуть в гидрониме «Кагалы» присутствие семантической коннотации. То есть обозначить и дополнительно выделить представление народной этимологии, отражающей его связь с глаголом «каяти», с непосредственно следующей покаянной молитвой: «...на рtцł

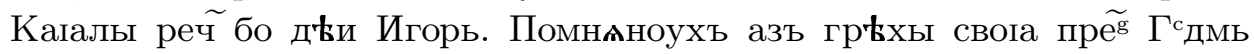
$\widetilde{\text { Бмъ моимъ }}{ }^{96}$.

Акцентировав внимание выше на эстетическом содержании анализируемой фразы, обратимся теперь к фонетико-семантической окраске явленной экстраординарной формы «Кагалы» как дополнительному инструменту воздействия на интеллектуально-эмоциональную сферу читателя. Ведь летописец, находясь в гипотетическом положении предпочтительного выбора из дилеммы «-t/-ы» для этого ключевого слова фразы, интуитивно руководствовался и идейно-эстетическим содержанием высказывания. Он должен был избрать наиболее адекватный ситуации вариант огласовки.

В своих экспериментаторских рассуждениях на этот счет мы исходим из положения, не раз озвученного авторитетными лингвистами в личных беседах: русский язык с XII века до настоящего времени в основе своей изменился мало (М. Г. Булахов). Г. А. Богатова, автор-составитель, редактор и главный редактор «Словаря русского языка XI-XVII вв.», отмечает, как бережно сохраняется основная

94 А. Зализняк, «Слово о полку Игореве»: Взгляд лингвиста, Москва 2004, с. 103, 104-105.

95 Полное собрание русских летописей.., т. 2, л. 223, 224 об.

96 Там же, л. 224 об. 
лексика, ссылаясь на лингво-статистические данные Н. В. Чурмаевой о том, что лишь $14 \%$ корней в русском языке XX века можно считать отжившими по сравнению с древнерусским периодом ${ }^{97}$. Эту точку зрения дополнительно подтверждают и относительно недавние указания на степень присутствия общеславянского лексического наследия в русском языке конца XX века. В книге А. Ф. Журавлева «Лексико-стилистическое моделирование системы славянского языкового родства» эта цифра оказывается наибольшей среди изученных объектов $-65,58 \%$. (Любопытно, что, разумеется из-за тематической ограниченности источников, в древнерусском - 35,48\%, старославянском - 14,87\% $\left.{ }^{98}\right)$. Эти обобщающие положения очевидно «поглощают» результаты таких диахронических процессов, как падение частотности «ы» начиная с XII-XIII ст. в связи со смягчением заднеязычных, падением «t» i t.p. Поэтому, считая, что мы имеем в современном языке результаты (промежуточные результаты?) этих процессов, полагаем допустимым применить фоносемантические характеристики звукобукв и слов русского языка, выработанные для нового времени во второй половине XX века А. П. ЖКуравлевым ${ }^{99}$. (Основные положения этой теории опираются на наблюдени над семиотической связью означающего с означаемым. Они сформировались еще в античности у Платона, четко и тонко рассматривались М. В. Ломоносовым в $\S 172,173$ «Краткого руководства к красноречию» и т.д. Конкретная методика фоносемантического исследования художественного текста разработана А. П. Журавлевым, она многократно апробирована как самим автором, так и его преемниками. Среди работ последних лет в этой области особенно впечатляют исследование смыслообразующего потенциала «Кыси» в одноименном романе Т. Толстой, предпринятое К. И. Барановой и А. А. Фоминым ${ }^{100}$, Л. Ю. Горнаковой ${ }^{101}$, а также наблюдения Т. М. Николаевой над художественными средствами древнерусского «Слова о полку Игореве»102.)

97 Г. Богатова, История слова как объект русской исторической лексикогра$\oint u и$, Москва 2008, с. 226-227.

98 А. Журавлев, Лексико-стилистическое моделирование системь славянского языкового родства, Москва 1994, с. 112-116.

99 А. Журавлев, Фонетическое значение, Ленинград 1974.

100 К. Баранова, А. Фомин, Кысь в «Кьиси»: смьслообразуюший потенииал литературного онима и механизмы его реализачии, «Вопросы ономастики» 2010, № 2 .

101 Л. Горнакова, Фонетический потенииал собственного имени в художественном тексте, «Филология и человек» 2010, № 1.

102 Т. Николаева, «Слово о полку Игореве». Поэтика и лингвистика текста; «Слово о полку Игореве» и пушкинские тексть, Москва 2005, с. 117. 
При этом «中», учитывая ее флексивное падежное положение, считаем дифтонгического происхождения [ие] и соотносим по современной звуковой шкале с ['e]. Мы не принимаем во внимание также поправочных коэффициентов, связанных с позицией звука в слове - повторяемость, положение первоначального, акцентность и частотность, - хотя два последних показателя, без сомнения, проявляли себя интенсивно. Это отмеченная выше рифменная связь «Кагалы» с «ны», «свои» и самая низкая среди гласных в современном языке частотность «ь́»-0,006, (для сравнения: «ы»-0,010; е - 0,050; é - 0,039) ${ }^{103}$.

Соглашаясь с мнением исследователя о том, что символика малочастотных, а значит высокоинформативных звуков в слове будет заметнее и потому может «сдвинуть» в свою сторону общее фонетическое значение комплекса ${ }^{104}$, мы все же будем исчислять значение проблемной звуковой оболочки гидронима исходя из наиболее жестких условий - усредненной символики каждого элемента. Ведь в сущности летописец (переписчик) как художник слова изначально мысленно стоял перед необходимостью свободного выбора звукоформы самого значимого в поэтической фигуре ингредиента и мысленно «реализовал» не столько грамматические варианты - соотношение окончания $\mathbf{k} / \mathbf{ы}$ - сколько адекватность своим интенциям одного из двух вариантов «Кагаль» или «Кагалы». Приведем здесь их характеристики по пятибалльной шкале, где крайние деления 1 и 5 означают превосходную степень антонимичных признаков, 2 и 4 - соответственные положительные степени и среднее деление 3 - нейтрально (напр.: «очень хороший» - «хороший» - «никакой, нейтральный» - «плохой», - «очень плохой») ${ }^{105}$. Просчитанные нами 25 фоносемантических показателей дают следующие картины. Для «Кагалы»:

\section{Шкала}

Большой - маленький

Храбрый - трусливый

Хороший - плохой

Могучий - хилый

Величественный - низменный

\begin{tabular}{c} 
результат \\
подсчетов \\
\hline 2,22 \\
2,36 \\
2,4 \\
2,44 \\
2,5
\end{tabular}

\section{характеристика}

большой храбрый почти хороший почти могучий почти величественный

103 А. Журавлев, Фонетическое значение..,, с. 123; А. Журавлев, Звук и смысл, Москва 1991, Приложение, таблица 2.

104 А. Журавлев, Фонетическое значение.., с. 117.

105 См.: А. Журавлев, Фонетическое значение..., с. 37, 50; А. Журавлев, Звук и смицсл.., с. 41. 
Сильный - слабый

Громкий - тихий

Простой - сложный

Гладкий - шероховатый

Красивый - отталкивающий

Яркий - тусклый

Радостный - печальный

Добрый - злой

Округлый - угловатый

Активный - пассивный

Легкий - тяжелый

Безопасный - страшный

Светлый - темный

Длинный - короткий

Подвижный - медлительный

Веселый - грустный

Нежный - грубый

Быстрый - медленный

Горячий - холодный

Женственный - мужественный

Для «Кая $\left[л^{\prime} \mathrm{e}\right] \gg:$

Хороший - плохой

Красивый - отталкивающий

Светлый - темный

Храбрый - трусливый

Простой - сложный

Округлый - угловатый

Добрый - злой

Радостный - печальный

Безопасный - страшный

Легкий - тяжелый

Гладкий - шероховатый

Активный - пассивный

Величественный - низменный

Веселый - грустный

Нежный - грубый

Яркий - тусклый

Могучий - хилый

Сильный - слабый
2,54

2,54

2,6

2,62

2,66

2,72

2,72

2,72

2,76

2,8

2,82

2,9

2,92

2,96

3,04

3,06

3,24

3,3

3,44

3,62

2

2,18

2,32

2,34

2,38

2,42

2,44

2,46

2,48

2,5

2,52

2,54

2,6

2,64

2,66

2,7

2,7

2,7 нейтральный нейтральный нейтральный нейтральный нейтральный нейтральный нейтральный нейтральный нейтральный нейтральный нейтральный нейтральный нейтральный нейтральный нейтральный нейтральный нейтральный нейтральный почти холодный мужественный

хороший

красивый

светлый

храбрый

простой

почти округлый почти добрый почти радостный почти безопасный почти легкий нейтральный нейтральный нейтральный нейтральный нейтральный нейтральный нейтральный нейтральный 


$\begin{array}{lll}\text { Большой - маленький } & 2,74 & \text { нейтральный } \\ \text { Громкий - тихий } & 2,76 & \text { нейтральный } \\ \text { Подвижный - медлительный } & 2,92 & \text { нейтральный } \\ \text { Длинный - короткий } & 3,0 & \text { нейтральный } \\ \text { Горячий - холодный } & 3,06 & \text { нейтральный } \\ \text { Быстрый - медленный } & 3,08 & \text { нейтральный } \\ \text { Женственный - мужественный } & 3,1 & \text { нейтральный }\end{array}$

Как видим, «Кагал'k»» воспринималось в качестве объекта действительности со следующими 10-ю информационными признаками: «хороший», «красивый», «светлый», «храбрый», «простой», «почти округлый», «почти добрый», «почти радостный», «почти безопасный», «почти легкий». Из них половина явлена ослаблено, нечетко: «почти округлый, - добрый, - радостный, - безопасный, - легкий». А те, первые 5 качеств в нашем перечне, что представлены в полной мере (хороший, красивый, светлый, храбрый, простой), неадекватны авторскому болезненному отношению к разгрому соотечественников в половецкой степи. В противоположность этому модусу «Кагалы» дает: «большой», «храбрый», «почти хороший», «почти могучий», «почти величественный», «почти холодный», «мужественный». Отчетливо и демонстративно здесь явлены три: «большой», «храбрый», «мужественный».

В этой психологически сложной ситуации лингво-фонетических и семантических полутонов автор сделал свой выбор в пользу «Кагалы» как поэтической формулы наиболее концентрированной и высоко значимой для его интенции. Ведь в качестве лексического неологизма оним был достаточно аморфным объектом русского грамматического поля, легко поддавался деформации парадигм склонений.

В связи со сказанным представляется важным еще одно обстоятельство, которое содержит в себе возможность не только дополнительно закрепить, но и несколько даже расширить перечень предложенных выше содержательных характеристик «Каялы». Мы обратимся к редко используемому в данном случае комплексу идейно-стилистических индивидуально-авторских особенностей древнего литератора.

Как известно, Ипатьевский рассказ об Игоревом походе изобилует нюансами, демонстрирующими обращение персонажей к Богу, желание постичь Его волю и выстроить свои социумные отношения, поступки в соответствии с ней. (Например, истолкование солнечного затмения Игорем и дружиной, молитва Игоря, аргументация решения сражаться пешими и т.д.) Эта целенаправленная избирательность хронистом религиозных фактов особенно очевидна при сопоставлении со «Словом о полку Игореве», на что не раз указывали медиевисты. 
Аналогичное отмечаем и в предшествующем тексте 6693 года. О русских князьях говорится: «и поидоша когождо во свогаси. (кож-

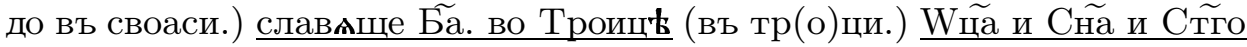
Дха.»106; «Игорь же молвашеть. (молвяше.) Стославлю моужеви. не

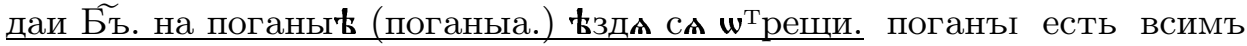
(поганыи ес всқм.) намъ шбечь (обчіи.) ворогъ.» (Подчеркнуто нами - Л.З. $)^{107}$.

Наряду с означенным мотивным слоем субъектов действий (ниже левый столбец) регистрируем и другой - субъекта повествования (правый столбец), - примыкающий к первому по семантике, но вполне самостоятельный и прежде всего выразительно отличный на его фоне в идейно-стилистическом ключе. (К сожалению, в нашей литературе эти текстовые зоны привычно не дифференцируются, а обобщенно именуются дидактизмом летописи, морализированием, назидательностью интерпретации и т.п.). Сопоставим их актуальные для нас черты:

1. Включает суждения, речи и т.п. многих персонажей;

2. импульсы участников событий;

3. представлены реально функционирующие, конкретные исторические лица;

4. персонажи могут изменять свои цели действий, нравственные установки;

5. руководствуются в своих действиях субъективно-неполным, предположительным постижением Божьей воли;

6. действия героев безотносительно к их личной воле диалектически последовательно в основе своей реализуют Божий промысел; 7. главные для них - «земные» цели и задачи, в реализации церковных догматов не столь активны; 1...единого субъекта - автора-повествователя;

2 ...стороннего наблюдателя за содеянным другими;

3...уподоблен лирическому герою, отсутствует его физическая локализация;

4...статичен в своих отправных параметрах оценки окружающего;

5...носитель знания Вышней абсолютной истины;

6...единственно верно сопрягает в своих суждениях конкретные события русской истории с религиозным провиденциализмом;

7 ...энергично декларирует свое видение и суд над всем происходящим на Руси как проводник прежде всего христианской идеи в ее абсолюте;

106 Полное собрание русских летописей.., т. 2, л. 222 об.

107 Там же, л. 223. 
8. все герои - представители высоких социальных сословий;

9. являют деятельность руководителей-иерархов, практически влияющих на формирование реально-политической обстановки;

10. слой их речений в целом дискретен, лишен логической преемственности, развития. Лишь условно, по тематической близости, является континуумом; 8...носитель лишь условного социального «титула», персоналия нравственной шкалы ценностей;

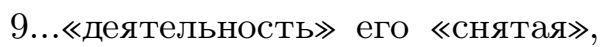
надпрактическая, нравственноучительная;

10...суждения диалектически связаны в единый художественный блок, который конденсирует в себе даже сюжетно обособленные новеллы 6693 года.

Обращает на себя внимание, что оба вербальных потока реализации христианской мысли в произведении существуют как бы параллельно, не пересекаясь и как бы невидимы один другому: герои не предполагают возможности оценки их деятельности со стороны хрониста, а последний непосредственно никогда не комментирует их мнений.

На фоне приведенных противопоставлений представляется возможным означить ряд дополнительных характеристик данной «прямой речи» летописца. Это прежде всего традиционно свойственные самостоятельному художественному произведению (а) экспозиция, (б) завязка, (в) кульминация, (г) развязка. Процитируем их соответственно.

А) Общий позитивный поток событий. Господь покровительствует и направляет деятельность русских князей, к ним благоволят и за них молятся святые мученики Борис и Глеб. Поэтому все предпринятое военначальниками свершается с Божьей помощью, успешно: «Съдыла

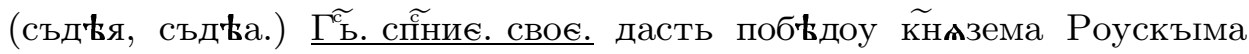

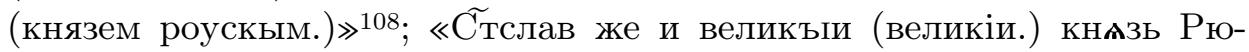
рикъ. побьдоу прїемша. (пріемше.) млгтвами. сто $($ с (вя)тою.) моучени-

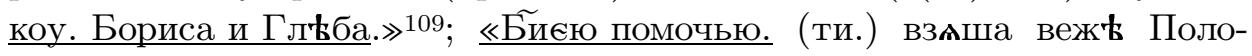
вецьк ки. ....на самыи великъ ден ${ }^{110}$.

Б) Герои перестают активно апелировать к волеизъявлению Бога, а пассивно полагаются на его предполагаемое покровительство русским. В результате на арену событий выступают диалектиче-

\footnotetext{
108 Полное собрание русских летописей..., т. 2, л. 222 об.

109 Там же.

110 Там же, л. 223.
} 
ски противоположные, антагонистические силы. Божьим попущением Игорь был ранен, омертвела его левая (Но не главная ролевая - правая. Этот факт обретает символическое значение) рука: «Сего есмы искаль. (искали.) а потлгнемъ. (потягным.) и тако поидоша к нимъ положаче (полочане, же) на Бзъ оупованиє. своє.» ${ }^{111}$; «и тако Биимъ попоущениемь. оу зввиша (оуязвиша.) Игорл в роукоу. и оумртвиша (оумрътвиша.) шюицю кго. (его.)»112.

В) В разделе кульминации расписывается, в чем конкретно проявился Божий суд и его цель - обращение к покаянию (молитва Игоря, плен, победы половцев в походах на беззащитную Русь): «И тако во

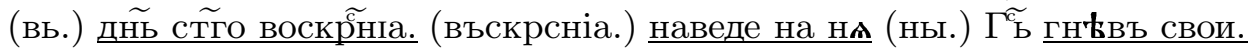
в радости мъсто наведе на ны плачь и во весельє (въ веселіа.) мъсто.

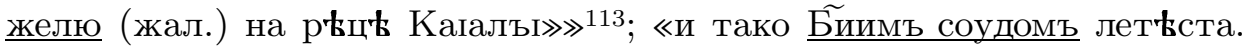

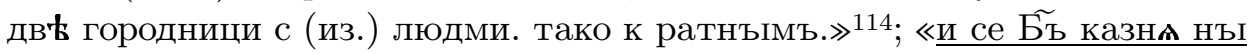
(нас.) грыхъ ради нашихъ. (за грыхы наша.) наведе на ны поганыла. не аки (акы.) милоуга ихъ. но насъ казня и шбращага ны (нас.) к покаганью. да быхом сл востлгноули (въстягноули.) $\boldsymbol{w}^{\mathrm{T}}$ злыхъ сво $\widetilde{\mathbf{n}^{\mathrm{x}}}$ дылъ. и симъ казнить ны (казнит нас, и сам нас казнит.) нахожениємь (нахожденіем.) поганыхъ. да некли (не како ли.) смиривошесл воспомлнемьсл (въспомянемся.) $\mathbf{w}^{\mathrm{T}}$ злаго поути.» ${ }^{115}$.

Г) В результате молитвы, раскаяния наступает релаксация. Господь сотворил избавление Игорю, уничтожены распри князей, Русь обращена в состояние восхождения к единению и могуществу: «를 шеть (в ддяше.) бо Бжига промысла. но творлше $\widetilde{\tau}($ творяшеся.) тамо

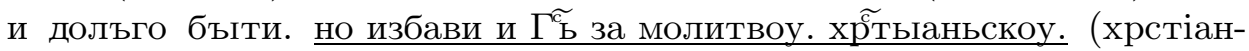
скоую.)» ${ }^{116}$; «се же избавлениє створи $\Gamma^{\widetilde{\mathrm{b}}}$ (сътвори г(оспод)ь избавленіе.) в плтокъ (пяк.) в вечерњ»»117. (Подчеркнуто нами - Л.3.).

Приведенные системы речений позволяют очертить лирический образ хрониста как далекий от самоуничижения, идейно мощный, властно оперирующий референциями, реализующий свои задачи в художественно безукоризненной форме. Именно в его «публицистическом» авторском слое находятся выделенные прежде стилистические фигуры.

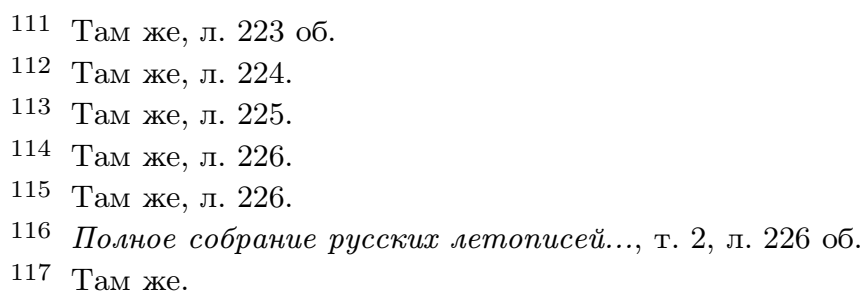


(Повторимся: организующие поэтику явленности в тексте смыслодоминирующих, жанрообразующих показателей - прежде всего временных.) Эти фигуры в сущности формируют кульминационную часть, реализуя тем самым наиважнейшую учительную задачу - христианской регламентации всего разнонаправленного и земно-суетного в жизни героев. Поэтому представляется естественным, что в их составе преобладает лексика абстрактная и возвышенная (гнев, радость, веселие, наказание, Бог, Господь, милость, грех и т.п.), а вовсе не конкретные, собственные стилистически нейтральные существительные, широко употребляемые и «затертые» географические онимы. Но если уж в гармонию этого пассажа включался конкретный гидроним, то он непременно должен был содержать некую привлекающую внимание странность, «изюминку» - быть фонетически, грамматически, семантически «свежим» и, возможно, не вполне освоеннорусским, чтобы обрести поэтически значимые коннотации, гибко подчиниться авторским интенциям. Так и произошло, по нашему мнению, с названием реки «Каялы». В общих силовых линиях летописного прецедента оно не мыслимо вне выражения некоего осуждения и покаяния в отношении к князю Игорю, некоторым русским князям и шире - общей современной политической истории Руси.

Эти же аргументы и в особенности предпринятая выше сфрагида литератора-повествователя сверх высказанных уже суждений дополнительно усиливают позицию, согласно которой лингво-семантический феномен «Каялы» является переходной ступенью освоения окказионального иноязычного слова в прогнозный родительный падеж русского языка, а употребление «на рłцł Каялы» без предложного повторения - релевантно. Ведь свойственное разговорно-фольклорному варианту «на реке на...» не только рационально вступает в противоречие с общей тематикой, тональностью и даже самой целью существования рассматриваемого пласта текста, но и на практике не реализовано. В 23 зарегистрированных нами сходных словосочетаниях «река» + гидроним, название местности или астионим по имени реки - в записях 6693 года нигде не встречается «популистский» вариант «на... + на...» как в известном смысле стилистически здесь неуместный. (Последнее говорит об исключительности позиции Ипатьевской летописи в традиционном медиевистическом образовании «текстологический треугольник», что может стать предметом самостоятельного изучения.)

По аналогии и в дополнение к изложенному, а также стремясь теоретически поддержать перспективность предпринятого феноменологи- 
ческого изучения древнего фрагмента, обратимся к авторитетному мнению на сей счет А. С. Пушкина.

Поэт как бы невзначай, смыслово-дополнительно, оценил коммуникативно-актуализирующие авторские речения в качестве самого креативносодержащего поля для наиболее вероятностных гипотетических силлогизмов филологов. Он, в 1836 году апеллируя к опыту знатоков «Слова о полку Игореве», особо выделил абзацем итоговую мысль своей статьи: «Других доказательств нет, как слова самого песнотворца» ${ }^{118}$.

Убежденность многих комментаторов в том, что они разделяют с Пушкиным понимание второй части фразы как 'текст всего произведения', на наш взгляд, опрометчива. Ибо уже в начале следующего предложения отчетливо дифференцируются означенные первоаргументом «слова самого песнотворца» и «сама песнь»: Подлинность же самой песни доказывается...119. А далее по «Слову» подробно анализируются вступительные фразы древнего Автора «Не льпо ли ны...» и т.д. Лишь с развитием сюжета произведения несколько затушевывается в герменевтических рассуждениях поэта это декларативно-четкое разделение обоих слоев в их художественном единстве.

\section{S T R E S Z C Z E N I E}

\section{HYDRONIM KAJAŁA W KRONICE IPATIJEWSKIEJ}

Artykuł stanowi wstępną część publikacji na temat cech semantyczno-gramatycznych i fonetycznych oraz funkcji ideowo-stylistycznych hydronimu rzeki Kajały. Dokonano przeglądu historii zagadnienia. Badacz wykorzystuje nie tylko tradycyjne podejście do tematu. Podejmuje próbę zbadania fonetyczno-semantycznej treści słowa jako centrum organizacyjnego poetyki kronikarza, zwłaszcza religijno-dydaktycznych motywów jego opowieści. Wskazano na elementy struktury epickiej i system figur poetyckich.

Słowa kluczowe: hydronim, alegoria, skrucha, nazwa-leksem, cechy semantyczno-gramatyczne i fonetyczne, obraz kronikarza.

118 А. Пушкин, Полное собрание сочинений: В 17 томах, Москва 1996, т. 12, с. 147.

119 Там же. 
S U M M A R Y

\section{HYDRONIM "KAYALA" IN IPATIJEVSKYA CHRONICLE}

The article represents the first part of the book devoted to the semantic-grammatical and phonetic features, idea-stylistic functions of the name of the Kayala river. The history of the problem is summarized. The researcher applies traditional procedures of the analysis and attempts to examine phonetic-semantic content of Kayala, treating the word as an organizing center of chronicler's poetry and religious-didactic motifs of his storytelling. Elements of epic structure, systems of poetic figures have been distinguished.

Key words: hydronim, allegory, repentance, name-lexeme, the semantic-grammatical and phonetic features, image of chronicler. 